\title{
Computational Social Choice and Challenges of Voting in Multi-Agent Systems
}

\author{
ZORICA A. DODEVSKA, Research and Development Institute Lola Ltd, Belgrade
}

Review paper

UDC: 005.311.6:004

DOI: 10.5937/tehnika1905724D

\begin{abstract}
The presence of big data, online systems, collaborations of remote agents, distributed knowledge, social media interaction, and generally, digital globalization, changes the way how people make decisions, and especially those of collective importance. We face numerous challenges of human and algorithm voting in multi-agent socio-technical environments. Computational Social Choice (COMSOC) has the tendency to join several separately studied fields. The author summarizes recent efforts that testify the importance of COMSOC and voting. This paper gives insights into the nature of voting in multi-agent systems (MAS) and related challenges, from both computational and social aspects. With respect to the challenging aspects of voting and specifics of MAS, the following directions for future research in the field of COMSOC are suggested: an integrated approach to voting, iterative voting, a voting argumentation framework, and combinatorial voting.
\end{abstract}

Key words: Computational Social Choice (COMSOC), voting, multi-agent systems (MAS), challenges, social challenges.

\section{INTRODUCTION}

Voting procedures, the main issues in Social Choice Theory, are getting more complex. An increasing number of people/agents are involved in defining problems and making joint decisions (the so-called collective decision-making). The issue of allocation of available resources becomes more pronounced having in mind the number of people and their needs. Also, increasing expertise is needed for the level of the problem under consideration, which is why Computer Science is of great help. Therefore, an emerging multidisciplinary discipline, called Computational Social Choice (COMSOC), has been catching the attention of researchers recently.

Generally, the presence of big data changes the way how researchers collect and process data, and there is a scientific paradigm shift towards COMSOC [1]. There is a great number of entities, as well as data about those entities. The question is how to use the data to acquire knowledge or make correct decisions. It is

Author's address: Zorica Dodevska, Research and Development Institute Lola Ltd, Belgrade, Kneza Višeslava 70a

e-mail: zorica.dodevska@li.rs

Paper received: 22.09.2019.

Paper accepted: 03.10.2019. important to make efforts in this area because the concept of „big data“ does not imply „big understanding" [2]. The instrument most commonly used for voting problem solving, i.e. preferences aggregation, is an algorithm. Traditional views are focused either on the computational challenges of voting algorithms or on different social issues of voting. The aim of this paper is to consider the challenges of both aspects of voting in accordance with the nature of decisionmaking in multi-agent systems (MAS) which is decentralised. The importance of COMSOC and voting for modern society will be discussed. After introducing the important concepts of voting theory in a multi-agent environment, computational and social challenges of voting will be presented. A necessity for their unity will be justified and several voting directions for MAS will be suggested.

\section{IMPORTANCE OF COMSOC AND VOTING}

COMSOC is a bridge between social and technical sciences, as well as classic and modern topics [3]. The author summarizes recent efforts in COMSOC and voting in the form of PESTLE (political, economic, social, technological, legal, and environment) framework (Table 1). It is evident that many factors affect this research area, and recurrently, COMSOC and voting affect modern society. 
Table 1. PESTLE framework of recent influencing factors regarding COMSOC and voting

\begin{tabular}{|c|c|c|}
\hline Political factors & Economic factors & Social factors \\
\hline $\begin{array}{l}\text { Political voting } \\
\text { systems - e.g. in } \\
\text { America [4] or in } \\
\text { Europe [5], } \\
\text { liquid democracy } \\
\text { [6], 'Brexit' } \\
\text { voting behaviour } \\
\text { [7] }\end{array}$ & $\begin{array}{l}\text { Crowdsourcing } \\
\text { [8], demographic } \\
\text { migrations [9] }\end{array}$ & $\begin{array}{l}\text { Collective } \\
\text { intelligence [10], } \\
\text { social network } \\
\text { and their impacts } \\
\text { on voting [11], } \\
\text { social welfare } \\
{[12]}\end{array}$ \\
\hline $\begin{array}{l}\text { Technological } \\
\text { factors }\end{array}$ & Legal factors & $\begin{array}{l}\text { Environmental } \\
\text { factors }\end{array}$ \\
\hline $\begin{array}{l}\text { Social } \\
\text { technologies } \\
\text { [13], } \\
\text { collaborative } \\
\text { technologies, } \\
\text { digital } \\
\text { technologies } \\
\text { [14], artificial } \\
\text { intelligence [3] } \\
\text { and social good } \\
\text { [15] }\end{array}$ & $\begin{array}{l}\text { Adoption of new } \\
\text { laws with } \\
\text { impacts on voting } \\
\text { (e.g. privacy and } \\
\text { data protection } \\
\text { regulations), } \\
\text { privacy } \\
\text { protection in } \\
\text { electronic voting } \\
\text { systems [16] }\end{array}$ & $\begin{array}{l}\text { Energy } \\
\text { consumption } \\
\text { issues [17] }\end{array}$ \\
\hline
\end{tabular}

There are many important issues and situations when a group is asked to decide about some choice. In those situations, the group reaches out to vote in order to achieve a consensus about the collective decision.

People express their stance on important issues by giving votes to preferable options. The voting process is the central area of COMSOC. Besides the act of voting itself, the computation of votes is from great influence for outcomes and, consequently, for social activities. Therefore, the voting process is a very responsible area. Finally, the right to vote, and generally, participation in making decisions is a cornerstone of democracy.

\section{VOTING IN MULTI-AGENT ENVIRONMENT}

Multi-agent systems consist of agents, physical or virtual entities [18], for example, people, independent organizations, software, virtual organizations, etc., that act, interact, and exchange information with other agents in common socio-technical environment. Those systems have uncertain and dynamic behaviour. Due to a distributed network of autonomous agents, decision making in MAS is decentralised and electronic voting is increasingly represented.

Individual entities that participate in decisionmaking (voters or agents) can have diverging, competing, or conflicting interests ([19], [20], [21]), and even dichotomous preferences [22]. Therefore, voting has a task to reconcile these differences.

Candidates or alternatives represent possible winners or potential winning ideas/proposals/solutions /characteristics under consideration. The basic idea is that the winning option should satisfy as many agents as possible (it is oriented to the whole voters' population). The previous selection procedure for candidates is necessary. As more ,tolerant” constraints expressed in the form of statements [3], preferences are central topics in decision-making. Also, they are a central focus in the field of artificial intelligence which deals with the replication of some human mind functions [23]. Especially, multi-agent preferences are not easy to introduce and elicit. Additional problematic may come from privacy issues or missing data [23].

A vote is a preference of an agent about given candidates that can be expressed in an ordering scale (the candidates are ranked) or on a cardinal scale (a utility index is assigned to each candidate). Also, it is possible only to name a favourite candidate/alternative. The outcome of voting can be one winner, more winners or their final order. The problem of aggregation of preferences is one of the crucial in the field of COMSOC. Listed are some of the most known voting rules in the literature [24], [25]:

- Majority - counting only first-place rated candidates (the winner has majority votes);

- Plurality - counting only first-place rated candidates (the winner has more votes than other candidates);

- Borda count method - counting the number of points that corresponds to the number of candidates which are ranked lower (the winner is a candidate with the highest score);

- Approval/K-approval - counting "approvals" so that each voter can approve any or $\mathrm{k}$ number of candidates and $\mathrm{k}$ is less than the total number of candidates (the winner is a candidate with the most ,approvals“);

- Copeland's method - counting the number of pairwise victories (the winner is a candidate with the highest number of pairwise victories);

- Veto - counting negative votes (the winner is a candidate with the least negative score).

Although apparently everything seems easy, the presence of social choice paradoxes illustrates shortcomings of voting systems. Namely, the outcome may not only depend on the voters' actions, for example:

- Condorcet paradox (voting paradox) - we can have cyclic collective preferences even if the individual ones are not cyclic;

- Arrow's paradox or Arrow's impossibility theorem - the impossibility of having an ideal social ordering that, under an unrestricted domain, it is Pareto efficient, independent of irrelevant alternatives, and not dictatorial and at the same time [26]; 
- Gibbard-Satterthwaite impossibility theorem - the impossibility of satisfaction the absence of the following undesirable properties: dictatorial voting, tactical voting, reducing the choice to only two alternatives.

The voting procedure can be expressed in the form of a set of instructions, i.e. algorithm, that decides about the winner. An understanding of algorithms requires examination of their full socio-technical assemblage [27]. Therefore, both computational and socials challenges must be considered.

\section{COMPUTATIONAL CHALLENGES OF VOTING}

Computational aspects of voting come from Computer Science and related fields as Artificial Intelligence - AI (with Machine Learning), Mathematics, Operations Research. They involve voting algorithm design and optimization, mathematical modelling, collective decision-making processing and analysing. Because of the non-linearity of MAS, there is a challenge in exact sciences known as computational complexity. Also, the decentralization of MAS opens the question of how to aggregate preferences. A lot of criteria should be satisfied. Computational challenges of voting are given in Table 2.

Table 2. Computational challenges of voting

\begin{tabular}{|c|c|c|}
\hline Aspect & Definition & Author(s) \\
\hline $\begin{array}{l}\text { Monotonicity } \\
\text { criterion }\end{array}$ & $\begin{array}{l}\text { It is not possible that a } \\
\text { candidate loses/wins if } \\
\text { we rank them } \\
\text { higher/lower (other } \\
\text { candidates are ranked } \\
\text { the same). }\end{array}$ & [28] \\
\hline $\begin{array}{l}\text { Computational } \\
\text { efficiency vs. NP- } \\
\text { hard voting } \\
\text { problem, } \\
\text { parameterized } \\
\text { complexity }\end{array}$ & $\begin{array}{l}\text { Input-output } \\
\text { transformation with } \\
\text { minimum resources and } \\
\text { with respect to the } \\
\text { complexity of the voting } \\
\text { rule. }\end{array}$ & $\begin{array}{l}{[29],[30],} \\
{[31]}\end{array}$ \\
\hline $\begin{array}{l}\text { Consistency } \\
\text { criterion }\end{array}$ & $\begin{array}{l}\text { The election of a joint } \\
\text { set of divided sets of } \\
\text { voters with the same } \\
\text { results gives also the } \\
\text { same result. }\end{array}$ & [24] \\
\hline Missing data & Incomplete preferences & {$[32]$} \\
\hline $\begin{array}{l}\text { Fairness, } \\
\text { accountability, and } \\
\text { transparency } \\
\text { (FAT) of } \\
\text { algorithmic } \\
\text { decision-making }\end{array}$ & $\begin{array}{l}\text { Decisions and } \\
\text { proceeding without } \\
\text { discrimination, i.e. } \\
\text { equitability, } \\
\text { responsibility for the } \\
\text { results, the openness of } \\
\text { procedures. }\end{array}$ & {$[33],[34]$} \\
\hline $\begin{array}{l}\text { Independence of } \\
\text { irrelevant } \\
\text { alternatives }\end{array}$ & $\begin{array}{l}\text { The order between the } \\
\text { two alternatives does not } \\
\text { change regardless of the } \\
\text { presence of the third } \\
\text { alternative. }\end{array}$ & {$[26],[35]$} \\
\hline
\end{tabular}

\section{SOCIAL CHALLENGES OF VOTING}

The social outcome of voting is very dependent on social dilemmas that exist between collective and individual rationality of self-interested agents [36]. Therefore, social aspects of voting are oriented toward humans (their behaviour, ethics, cognitive reasoning) and the broader idea of higher purpose and justice, and they are placed in a voting social context. The aspects come from Social Choice Theory and related fields as Economics, Political Science, Philosophy, and Psychology.

The voting process takes place under the veil of interactions among intelligent agents that can be human or artificial ones. Therefore, the voting population as a complex adaptive system has uncertain behaviour. Social challenges of voting are given in Table 3 .

Table 3. Social challenges of voting

\begin{tabular}{|c|c|c|}
\hline Aspect & Definition & Author(s) \\
\hline $\begin{array}{l}\text { Selection of } \\
\text { candidates }\end{array}$ & $\begin{array}{l}\text { The way how candidate } \\
\text { close list is created. }\end{array}$ & {$[37]$} \\
\hline Voter turnout & $\begin{array}{l}\text { It presents the percentage of } \\
\text { votes relative to the voter } \\
\text { population. }\end{array}$ & {$[38],[39]$} \\
\hline $\begin{array}{l}\text { Manipulation vs. } \\
\text { strategy-proof }\end{array}$ & $\begin{array}{l}\text { Strategic voting vs. } \\
\text { nonmanipulable voting }\end{array}$ & {$[40],[41]$} \\
\hline Privacy issues & $\begin{array}{l}\text { Voter privacy data } \\
\text { protection }\end{array}$ & {$[42]$} \\
\hline \multirow{3}{*}{$\begin{array}{l}\text { Different } \\
\text { negative aspects } \\
\text { of voter } \\
\text { behaviour }\end{array}$} & $\begin{array}{l}\text { Bias - favouritism of some } \\
\text { candidate (s) }\end{array}$ & {$[43],[44]$} \\
\hline & $\begin{array}{l}\text { Prejudice - unfounded } \\
\text { preconceptions }\end{array}$ & {$[45]$} \\
\hline & Bribery - corrupt voting & {$[46]$} \\
\hline \multirow{3}{*}{$\begin{array}{l}\text { The presence of } \\
\text { paradoxes in } \\
\text { Social Choice } \\
\text { Theory }\end{array}$} & $\begin{array}{l}\text { Condorcet paradox (voting } \\
\text { paradox) }\end{array}$ & {$[47],[48]$} \\
\hline & $\begin{array}{l}\text { Arrow's paradox (Arrow's } \\
\text { impossibility theorem) }\end{array}$ & {$[26],[49]$} \\
\hline & $\begin{array}{l}\text { Gibbard-Satterthwaite } \\
\text { impossibility theorem }\end{array}$ & {$[50]$} \\
\hline $\begin{array}{l}\text { Anonymity and } \\
\text { neutrality }\end{array}$ & $\begin{array}{l}\text { The outcome of a voting } \\
\text { rule does not depend on } \\
\text { voters'/candidates' identities } \\
\text { or the order they are } \\
\text { considered. }\end{array}$ & {$[24],[51]$} \\
\hline $\begin{array}{l}\text { Non-dictatorship } \\
\text { voting }\end{array}$ & $\begin{array}{l}\text { There is no single powerful } \\
\text { voter whose preference } \\
\text { decides group preference. }\end{array}$ & {$[26]$} \\
\hline
\end{tabular}

\section{IMPLICATIONS FOR FUTURE WORK}

Having in mind the social and computational challenges of voting and specifics of MAS, some possible directions for future research can be suggested, which are in the spirit of COMSOC. 


\subsection{Integrated approach to voting}

The study of decision making in MAS demands a holistic approach. Voting, or collective decision making, takes place in the dual socio-technical environment, where humans and algorithms parallelly make decisions substantial for society. COMSOC demands theoretical modelling and algorithm design [52], as well as social context consideration of voting.

There are many examples that put clear the connection and the need for integrated studies in this complex field. For example, we can parallelly discuss computational complexity and social complexity of voting in MAS, incomplete preferences and privacy issues [22], human and algorithmic biases, or we can work on how to design an NP-hard voting rule that makes difficult to cheat [53], etc. Although manipulation of voting is a social phenomenon, computational hardness is the main obstruction to manipulation [54].

\subsection{Iterative voting}

Iterative voting is convenient in dynamic and unpredictable MAS because it allows voters to change their preferences iteratively, toward collective consensus - equilibrium [55]. It allows them to get the additional information and gain insight into the broader picture, after learning in each iteration [56], which is not possible in a priori approach. This is an important prerequisite for better understanding and meeting the voting criteria. The approach is especially useful in the domain of AI where artificial agents or "voting avatars" [57] are capable of reinforcement learning.

Generally, a fertile ground for this challenge is possible to find in the intersection of AI, social science, and human-computer interaction, called human-agent interaction or Explainable AI [58]. Sequential or multistage approach [59] in combination with an interactive approach, for example, by asking users a series of informative questions [60], is one of the possible ways of learning about agent's preferences that should be done iteratively.

\subsection{Voting argumentation framework}

In voting, besides the central question ,how to aggregate", there is also an important question ,what to aggregate" [61]. Therefore, Karanikolas et al. [1] suggest the voting argumentation framework that combines preference aggregation with preference argumentation (i.e. COMSOC with argumentation). Justification of agents' preferences is not the focus of classic social choice methods [63]. Unjustified preferences itself are not enough and there is a need for its reasoning [62]. Furthermore, some authors are developed computational models for a better understanding of individual preferences (for example, VAMP or
Voting Agent Model of Preferences [64]), which can be useful before its aggregation.

\subsection{Combinatorial voting}

Combinatorial voting refers to voting in multiissue domains which means that the set of alternatives has a combinatorial structure [65]. Hence, voting in combinatorial domains deals with complex combinatorial structures [66]. One example is sequential voting when agents vote by a local voting rule on one issue at a time [24], which represents one kind of decomposition of the initial problem. Depending on a specific context, the same voting rule does not have to be equally efficient throughout all steps of a voting procedure.

\section{CONCLUSION}

The importance of voting in multi-agent systems is emphasized in this paper. COMSOC as a multidisciplinary field connects several significant spheres of influence of today's global scientific and technological trends. PESTLE framework of recent influencing factors underlines the importance of COMSOC and voting for solving significant problems in society.

Voting, as the main collective decision-making mechanism in multi-agent systems, demand consideration of both computational and social aspects, which are interwoven in voting problematics. The challenging aspects are presented in the paper.

The paper also contributes to the existing corpus of knowledge by suggesting and explaining several possible research directions on the basis of the previous study of both aspects and the nature of voting in multiagent systems.

\section{REFERENCES}

[1] Chang R. M, Kauffman R. J, Kwon Y. O, Understanding the paradigm shift to computational social science in the presence of big data, Decision Support Systems, Vol. 63, pp. 67-80, 2014.

[2] Lippe M, Bithell M, Gotts N, Natalini D, BarbrookJohnson P, Giupponi C, Hallier M, Hofstede G. J, Le Page C, Matthews R. B, Schlüter M, Smith P, Teglio A, Thellmann K, Using agent-based modelling to simulate social-ecological systems across scales, GeoInformatica, Vol. 23, No. 2, pp. 269-298, 2019.

[3] Rossi F, Venable K. B, Walsh T. A Short Introduction to Preferences: Between AI and Social Choice, Morgan \& Claypool Publishers, 2011.

[4] Hammond T. H, A unified spatial model of American political institutions, in: Heckelman J, Miller NR (Ed.), Handbook of Social Choice and Voting, Ch. 11, Edward Elgar Publishing, 2015. 
[5] Laslier J. F, Blais A, Bol D, Golder S. N, Harfst P, Stephenson L. B, der Straeten K. V, The EuroVotePlus experiment, European Union Politics, Vol. 16, No. 4, pp. 601-615, 2015.

[6] Kahng A, Mackenzie S, Procaccia A. D, Liquid democracy: An algorithmic perspective, in Proc. 32th AAAI Conference on Artificial Intelligence (AAAI18), AAAI Press, pp. 1095-1102, 2018.

[7] Hobolt S. B, The Brexit vote: a divided nation, a divided continent, Journal of European Public Policy, Vol. 23, No. 1, pp. 1259-1277, 2016.

[8] Prpić J, Shukla P. P, Kietzmann J. H, McCarthy I. P, How to work a crowd: Developing crowd capital through crowdsourcing, Business Horizons, Vol. 58, No. 1, pp. 77-85, 2015.

[9] Klabunde A, Willekens F, Decision-Making in Agent-Based Models of Migration: State of the Art and Challenges, European Journal of Population, Vol. 32, No. 1, pp. 73-97, 2016.

[10]Piccolo LSG, Liddo A. D, Burel G, Fernandez M, Alani H, Collective intelligence for promoting changes in behaviour: a case study on energy conservation, AI \& SOCIETY, Vol. 33, No. 1, pp. 15-25, 2018.

[11]Reed M, Social network influence on consistent choice, Journal of Choice Modelling, Vol. 17, pp. 28-38, 2015.

[12]Sen A, Collective Choice and Social Welfare: An Expanded Edition, Harvard University Press, Cambridge, Massachusetts, 2017.

[13]Skaržauskienè A, Tamošiūnaitė R, Žalènienė I, Defining Social Technologies, in Proc. 4th International Conference on IS Management and Evaluation: ICIME 2013, Vietnam, pp. 239-246, 13-14 May 2013.

[14]Cheeseman N, Lynch G, Willis J, Digital dilemmas: the unintended consequences of election technology, Democratization, Vol. 25, No. 8, pp. 1397-1418, 2018.

[15]Hager G. D, Drobnis A, Fang F, Ghani R, Greenwald A, Lyons T, Parkes D. C, Schultz J, Saria S, Smith S. F, Tambe M, Artificial Intelligence for Social Good, Workshop Report, Computing Community Consortium, Washington, 2017.

[16]Yu S. Big, Privacy: Challenges and Opportunities of Privacy Study in the Age of Big Data, IEEE Access, Vol. 4, pp. $2751-2763,2016$.

[17]Carreira P, Costa A. A, Mansur V, Arsénioa A, Can HVAC really learn from users? A simulation-based study on the effectiveness of voting for comfort and energy use optimization, Sustainable Cities and Society, Vol. 41, pp. 275-285, 2018.

[18]Ferber J, Multi-Agent System: An Introduction to Distributed Artificial Intelligence, Addison Wesley Longman, Harlow, 1999.

[19]Procaccia A. D, Rosenschein J. S, Junta Distributions and the Average-Case Complexity of Manipulating Elections, Journal of Artificial Intelligence Research, Vol. 28, pp. 157-181, 2007.

[20]Artikis A, Sergot M, Pitt J, Busquets D, Riveret R, Specifying and Executing Open Multi-agent Systems, in: Aldewereld H. et al. (Eds.), Social Coordination Frameworks for Social Technical Systems, pp. 197-212, Springer, Cham, 2016.

[21]Anshelevich E, Postl J. Randomized social choice functions under metric preferences. Journal of Artificial Intelligence Research, Vol. 58, No. 1, pp. 797$827,2017$.

[22]Vorsatz M, Approval voting on dichotomous preferences. Social Choice Welfare, Vol. 28, No. 1, pp. 127-141, 2007.

[23]Rossi F, Preferences, Constraints, Uncertainty, and Multi-Agent Scenarios, ISAIM, 2008.

[24]Cornelio C, Pini M. S, Rossi F, Venable K.B, Multiagent soft constraint aggregation via sequential voting: theoretical and experimental results, Autonomous Agents and Multi-Agent Systems, Vol. 33, No. 1-2, pp. 159-191, 2019.

[25]Talib F, Computational aspects of voting: a literature survey, Thesis, Rochester Institute of Technology, RIT Scholar Works, 2007.

[26]Arrow K. J, Sen A. K, Suzumura K, Handbook of social choice and welfare, Volume 2, Elsevier, North-Holland, 2011.

[27]Kitchin R, Thinking critically about and researching algorithms, Information, Communication \& Society, Vol. 20, No. 1, pp. 14-29, 2017.

[28]Sánchez-Fernández L, Fisteus J, A, Monotonicity Axioms in Approval-based Multi-winner Voting Rules. In Proc. 18th International Conference on Autonomous Agents and Multiagent Systems (AAMAS 2019), Montréal, Canada, 9 pages, 13-17 May 2019.

[29]Chen J, Exploiting Structure in Computationally Hard Voting Problems, Universitätsverlag der TU Berlin, 2016. 
[30]Dorn B, Schlotter I, Having a Hard Time? Explore Parameterized Complexity!, in: Endriss U. (Ed.), Trends in Computational Social Choice, Ch. 11, AI Access, 2017.

[31]Bredereck R, Chen J, Faliszewski P, Guo J, Niedermeier R, Woeginger G. J, Parameterized Algorithmics for Computational Social Choice: Nine Research Challenges. Tsinghua Science and Technology, Vol. 19, No. 4, pp. 358-373, 2014.

[32]Konczak K, Lang J, Voting procedures with incomplete preferences. In Proceedings of the Multidisciplinary Workshop on Advances in Preference Handling, 2005.

[33]Lepri B, Oliver N, Letouzé E, Pentland A, Vinck P, Fair, Transparent, and Accountable Algorithmic Decision-making Processes: The Premise, the Proposed Solutions, and the Open Challenges. Philosophy \& Technology, Vol. 31, No. 4, 2018.

[34]Corbett-Davies S, Goel S, The Measure and Mismeasure of Fairness: A Critical Review of Fair Machine Learning. arXiv:1808.00023v2 [cs.CY] 14 Aug 2018

[35]Benson A. R, Kumar R, Tomkins A, On the Relevance of Irrelevant Alternatives, International World Wide Web Conference Committee (IW3C2), pp. 963 973, Montréal, Québec, Canada, 11-15 April 2016.

[36]Leibo J. Z, Zambaldi V, Lanctot M, Marecki J, Graepel, T, Multi-agent Reinforcement Learning in Sequential Social Dilemmas. arXiv:1702.03037v1 [cs.MA] 10 Feb 2017

[37]Fernandes J. M, Geese L, Schwemmer C, The impact of candidate selection rules and electoral vulnerability on legislative behaviour in comparative perspective, European Journal of Political Research, Vol. 58, No. 1, pp. 270-291, 2019.

[38]Cancela J, Geys, B, Explaining Voter Turnout: A Meta-Analysis of National and Subnational Elections. Electoral Studies, Vol. 42, pp. 264-275, 2016.

[39]Green D. P, Gerber A. S, Get Out the Vote: How to Increase Voter Turnout, 3rd edition, Brookings Institution Press, 2015.

[40]Conitzer V, Walsh T, Barriers to Manipulation in Voting, in: Brandt F et al. (Eds.), Handbook of Computational Social Choice, Ch. 6, Cambridge University Press, New York, NY, USA, 2016.

[41]Islam J. N, Mohajan H. K, Moolio P, Method of Voting System and Manipulation of Voting, International Journal of Management and Transformation, Vol. 5, No. 1, pp. 10-34, 2011.
[42]McCorry P, Shahandashti S. F, Hao F, A smart contract for boardroom voting with maximum voter privacy, in: Kiayias A. (Eds.), Financial Cryptography and Data Security, Ch. 20, Springer, Cham, 2017.

[43]Pianzola J. Selection biases in Voting Advice Application research, Electoral Studies, Vol. 36, pp. 272-280, 2014.

[44]Olivola C. Y, Funk F, Todorov A. T, Social attributions from faces bias human choices, Trends in $\mathrm{Co}$ gnitive Sciences, Vol. 18, No. 11, pp. 566-570, 2014.

[45]Hutchings P. B, Sullivan K. E, Prejudice and the Brexit vote: a tangled web, Palgrave Communications, Vol. 5, 5 pages, 2019.

[46]Dey P, Misra N, Narahari Y, Frugal bribery in voting, Theoretical Computer Science, Vol. 676, pp. 15-32, 2017.

[47]Zhang Y, Bouadi T, Martin A. Preference fusion and Condorcet's paradox under uncertainty, 20th International Conference on Information Fusion - FUSION 2017, Xi'an, China, 10-13 July 2017. HAL Id: hal-01573217.

[48]Herings PJ-J, Houba H, The Condorcet paradox revisited, Social Choice and Welfare, Vol. 47, No. 1, pp. 141-186, 2016.

[49]Miller N. R, Reflections on Arrow's theorem and voting rules, Public Choice, Vol. 179, No. 1-2, pp. 113-124, 2019.

[50]Bade S, Gonczarowski Y. A, Gibbard-Satterthwaite Success Stories and Obvious Strategyproofness, arXiv:1610.04873v3 [cs.GT] 18 Mar 2017

[51]Brandt F, Rolling the Dice: Recent Results in Probabilistic Social Choice, in: Endriss U (Ed.), Trends in Computational Social Choice, Ch. 1, AI Access.

[52]Lu W, Computational Social Influence: Models, Algorithms, and Applications, Thesis, The University of British Columbia, Vancouver, 2016.

[53]Endriss U, Computational Social Choice: Prospects and Challenges, Procedia Computer Science, Vol. 7, pp 68-72, 2011.

[54]Dey P, Misra N, Narahari Y, Complexity of manipulation with partial information in voting, Theoretical Computer Science, Vol. 726, pp. 78-99, 2018.

[55]Koolyk A, Strangway T, Lev O, Rosenschein J. S, Convergence and Quality of Iterative Voting Under Non-Scoring Rules. In Proc. Twenty-Sixth International Joint Conference on Artificial Intelligence 
(IJCAI-17), pp. 273-279, Melbourne, Australia, 1925 August 2017.

[56]Airiau S, Grandi U, Perotto F. S, Learning Agents for Iterative Voting. In Proc. 5th International Conference on Algorithmic Decision Theory (ADT 2017), pp. 139-152, Luxembourg, Luxembourg, 25-27 October 2017.

[57]Grandi U, Agent-Mediated Social Choice. ArXiv: $1806.07199 \mathrm{v} 2$ [cs.AI] $10 \mathrm{Jul} 2018$

[58]Miller T, Explanation in Artificial Intelligence: Insights from the Social Sciences, arXiv:1706.07269v3 [cs.AI] 15 Aug 2018

[59]Barberà S, Gerber A, Sequential voting and agenda manipulation, Theoretical Economics, Vol. 12, pp. 211-247, 2017.

[60]Viappiani P, Preference Aggregation, Preference Elicitation, and Preference Learning, 2017 Computational Decision Making and Data Science, Belgrade, Serbia, 12 - 13 July 2017.

[61]Gustavo B, Fernando T, Marcelo A, Collective argumentation: A survey of aggregation issues around argumentation frameworks, Argument \& Computation, Vol. 8, No. 1, pp. 1-34, 2017.
[62]Karanikolas N, Bisquert P, Kaklamanis C, A Voting Argumentation Framework: Considering the Reasoning behind Preferences. In Proc. 11th International Conference on Agents and Artificial Intelligence ICAART 2019, pp. 42-53, Prague, Czech Republic, 19 - 21 February 2019. HAL Id: lirmm-02180472

[63]Bisquert P, Croitoru M, Kaklamanis C, Karanikolas $\mathrm{N}$, A decision-making approach where argumentation added value tackles social choice deficiencies, Progress in Artificial Intelligence, Vol. 8, No. 2, pp. 229-239, 2019.

[64]Bergner A. S, Oppenheimer D. M, Detre G, VAMP (Voting Agent Model of Preferences): A computational model of individual multi-attribute choice, Cognition, Vol. 192, 103971, 2019.

[65]Xia L, Introduction to Combinatorial Voting, in: Computational Voting Theory: Game-Theoretic and Combinatorial Aspects, Ph.D. Dissertation, Ch. 8, pp. 149-165, Computer Science Department, Duke University, Durham, NC, August 2011.

[66]Lang J, Xia L, Voting in combinatorial domains, in: Brandt $\mathrm{F}$ et al. (Eds.), Handbook of Computational Social Choice, Ch. 9, pp. 197-222, Cambridge University Press, New York, NY, USA, 2016.

\section{REZIME}

\section{RAČUNARSKI DRUŠTVENI IZBOR I IZAZOVI GLASANJA U MULTIAGENTNIM SISTEMIMA}

Prisustvo „,big data“, „online“ sistema, saradnja udaljenih agenata, distribuirano znanje, interakcija na društvenim medijima, i uopšte, digitalna globalizacija, menja način na koji ljudi donose odluke, a posebno one od kolektivnog značaja. Suočavamo se sa brojnim izazovima glasanja u multiagentnom društveno-tehničkom okruženju, koji dolaze kako od ljudi tako i od algoritama. Računarski društveni izbor (engl. Computational Social Choice - COMSOC) ima tendenciju da objedini nekoliko odvojeno proučavanih oblasti. Autor rezimira nedavne napore koji svedoče o važnosti COMSOC-a i glasanja. Ovaj rad pruža uvid u prirodu glasanja u multiagentnim sistemima, kao i sa njom povezanim izazovima, kako sa računarskog tako i sa društvenog aspekta. Uzimajući u obzir izazovne aspekte glasanja $i$ specifičnosti multiagentnih sistema, predloženi su sledeći pravaci za buduća istraživanja u oblasti COMSOC-a: integrisani pristup glasanju, iterativno glasanje, okvir za argumentovano glasanje, $i$ kombinatorno glasanje.

Ključne reči: Računarski društveni izbor, glasanje, multiagentni sistemi, računarski izazovi, društveni izazovi 